\title{
Conferences/Seminars
}

\section{North African Conferences on Islamic Themes} Zaghwān, Tunisia

Sha'bä 7-11, 1409/March 15-19, 1989

\section{Rabat, Morocco}

Shawwäl 25-27, 1409/May 31-June 2, 1989

This past spring has seen two important conferences on Islamic topics which merit observation.

In mid March CEROMDI, or the Study and Research Centre on Ottoman and Morisco Documentation and Information (Centre d'Etudes et de Recherches Ottomanes, Morisques, de Documentation et d'Information) held the Fourth International Symposium on Morisco Studies in Zaghwān, approximately $80 \mathrm{~km}$ south of Tunis, and in the capital of Tunis itself, in the Hotel du Lac. This meeting lasted from March 15-19, 1989.

The conference was made possible largely due to the enthusiasm of Professor Abdeljalil Temimi, of Morisco descent himself, and was inaugurated in the CEROMDI library which Prof. Temimi has built with his own funds in the Morisco city of Zaghwann. The ceremony was attended by members of the government and diplomatic corps as well as professors from all over the Western Mediterranean area. The topics of the symposium covered the art and handicrafts of the Moriscos who were exiled from Spain in 1610, their religious life and the rich legacy they have left in Morocco, Algeria and Tunisia, as well as in several libraries in Spain itself and elsewhere, such as Paris and Cambridge.

Participants came from France, Spain, Portugal, Morocco, Algeria, Egypt, Saudi Arabia, the United States and Puerto Rico. Their papers covered many fields, such as interpretation of their documents and description of their heritage. The Spanish delegation was led by the dean of Morisco studies in that country, Professor Alvaro Galmés de Fuentes, formerly of the University of Oviedo in Asturias and now from the Central University in Madrid; and Mikel de Epalza from Alicante. Others were Professor Consuelo LópezMorillas from Indiana University, and María Teresa Narvaez from the University of Puerto Rico in Ró Piedras. The latter spoke on Mancebo de Arevalo, an important yet somewhat mysterious intellectual leader of the persecuted Muslims of Castile in central Spain in the 1520 s and 1530 s, almost the same time as the picaro Lazarillo de Tormes. Communications were in French, Arabic, English and Spanish. 
The Moriscos were Muslims who, from the repudiation of the Treaty of Granada in 1499 by Cardinal Ximénez de Cisneros, (which had been signed in 1492 at the fall of that last Muslim capital of Spain), were forced as Granadines to become (nominal) Christians. If they would not, they had to leave Spain, or were jailed and tortured. Their books and documents were confiscated and destroyed (as were similar manuscripts in Mexico during these same years, and under these same laws, so that Mexico thereby lost an important part of its history). Their mosques were confiscated and turned into churches, stables or warehouses.

From that time on, the Catholic state began to repudiate the rights of the Spanish Muslims in the kingdoms of Castile, Aragon and, especially, Valencia. Once these Muslims had accepted Catholicism, willingly or unwillingly, and generally by decree, they were subject to arrest and trial by the so-called "Holy" Office of the Inquisition. They had to pay for their incarceration by the sale of their personal property, and thousands of families were made destitute even before a trial was instituted; Muslim women and children were subjected to abuse by the Inquisitorial authorities and the general public; Muslim girls were sold as slaves for immoral purposes and only incidentally to make them Christians.

In 1668 the peasants and artisans in the Alpujarras mountains to the southeast of Granada rose in revolt, demanding their freedom from this religious tyranny, but they were savagely repressed by Pedro de Deza of the "Holy" Office, and King Philip IIs illegitimate half-brother don Juan de Austria. They were hunted down brutally, families being split up and dispersed into other parts of Spain. Their suffering was unimaginable. It was an offense NOT to eat pork or drink wine, and a crime (under Spanish Catholic law) to be caught praying to God Alone.

After 1671, Muslim houses had to have their doors and windows open on Fridays so the authorities (and inquisitive neighbors) might be sure that the inmates were not offering Friday prayers. Anyone caught in such "illegal" activity could be jailed and, still worse, flogged or sent to the galleys as slaves. Hundreds of Muslims, especially in and around Valencia on the Mediterranean coast, were burned at the stake for their loyalty to God Alone, and their refusal to bow down before graven images.

Meanwhile the few leaders who were left tried to compile lesson materials and poems for young Muslims. These were mostly written in "al jamiado" (spanish) al'ajamiyah or Arabic script, just as Persian and Urdu are still written in this manner.

These manuscripts have been found over the past century, hidden away for a future time of less persecution. Professor Julian Ribera was active in this search. They have been found chiefly in and around Zaragoza in northeastern Spain where an important centre of Islam existed ever since 
the Visigothic Unitarians or Arians became Muslim shortly after the Arab conquest in the eighth century. The documents have been studied not for their religious or historic content but because the Arabic script gives linguists a way to actually see the pronunciation of Spanish four and five hundred years ago, almost like a tape recording today.

It is important that some of their work be taken over by Muslim scholars so that these lesson materials can be used for dawa work in Latin America and Spain itself. They will show the new Muslims who are appearing in those countries that Islam for nine full centuries (from 711 until 1610) was an important part of Spanish life which gave Spain (and Latin America) its most historic buildings, especially in Andalusia (and even in important centres in Latin America during the first part of the conquest of those areas).

From May 31st to June 2nd, another conference was held, in Rabat, Morocco, for the "Correction of Erroneous Information Published on Islam" because of Salman Rushdie's Satanic Verses. This second conference or round table was samller than the one in Tunis, and consisted of several specialists from Morocco, Pakistan, the United States, Britain, etc., who discussed Rushdie's book. This meeting was sponsored by ISESCO, the Islamic Educational, Social, and Cultural Organization of OIC (the Organization of the Islamic Conference).

For this participant in the meeting, the chief feature was the opportunity to meet a panel of experts from several Muslim and non-Muslim countries, who discussed the implications of this vulgar publication. After reading papers and discussing the same, a report was made to ISESCO which will be published shortly.

One pleasant aspect of this conference was meeting several of the leaders of the Morisco community in Rabat. They are still there or, rather, their proud descendants are, and they form the leadership of much of Moroccan intellectual life.

From both these conferences, it seems that Islam and its history, especially on these controversial issues, is not well known by either Muslims themselves or by the non-Muslim public. It is easy to spread misinformation of the Rushdie sort, or to cloak important literary material like the Morisco poetry under the study of linguistics, so this does not reach the public, which needs to learn more and more about Islam as this religion continues to revive and spread.

We therefore need a research center or centers in the Islamic world where this material can be sifted and, if possible, lead some younger scholars on to higher degrees in these recondite fields. In any case there are a few centers where this is studied including Bloomington, Indiana; Cambridge; London; Oviedo, Alicante and Madrid in Spain; and Rio Piedras, Puerto Rico. The Islamic Universities in Madina, Islamabad and Malaysia might consider opening departments of Morisco and similar studies, and of dawa based on 
this research for Latin America (where the use of Spanish and Portuguese are essential).

With the Rushdie material, what is shown is the utter ignorance of Islam by the media and European and American information centers. Rather than provide information on Islam, they repeat folklore from the Crusading and Zionist clashes which have been the stock-in-trade of their press releases: "Moslem" instead of Muslim, for instance, "Khadafi" as in the name of the head of state in Libya, "Koran" for Qur'an, "Sabbath" for Friday yawm aljuma, and not yawm al-sabt, and so forth.

The cure for this misinformation should be that Islamic agencies like ISESCO and IIIT should hold conferences on various topics that need discussion, such as the matter of Islamic terms and values; the place of women in Islam; and the use of communications and electronic media in the modern age. These should be held in various world centers, inviting a few (not many) non-Muslim "experts," and carried on in a non-controversial manner with the object of informing the public at large.

We need to evaluate our own intellectual resources, muster them, and then consider how to meet these challenges. Islam has been meeting them defensively, whereas the fifth of the world which is Muslim should be able to speak for itself and with the variety of opinion that a great world religion merits.

T. B. Irving

Cedar Rapids, Iowa 